Article

\title{
Dual Substitution and Spark Plasma Sintering to Improve Ionic Conductivity of Garnet $\mathrm{Li}_{7} \mathrm{La}_{3} \mathrm{Zr}_{2} \mathrm{O}_{12}$
}

\author{
Zhencai Dong ${ }^{1,+}$, Chao $\mathrm{Xu}^{2,+}$, Yongmin $\mathrm{Wu}^{3}$, Weiping Tang ${ }^{3}$, Shufeng Song ${ }^{1, *}$, Jianyao Yao ${ }^{1, *}$, \\ Zhengyong Huang ${ }^{2}$, Zhaoyin Wen ${ }^{4}$, $\mathrm{Li} \mathrm{Lu}^{5,6}$ and Ning $\mathrm{Hu}{ }^{1,7,8, *(1)}$ \\ 1 College of Aerospace Engineering, Chongqing University, Chongqing 400044, China; \\ 20163113037@cqu.edu.cn \\ 2 College of Electrical Engineering, Chongqing University, Chongqing 400044, China; \\ xuchao1995@cqu.edu.cn (C.X.); huangzhengyong@cqu.edu.cn (Z.H.) \\ 3 State Key Laboratory of Space Power-sources Technology, Shanghai Institute of Space Power-Sources, \\ Shanghai 200245, China; wuym2014@126.com (Y.W.); tangwp@sina.cn (W.T.) \\ 4 CAS Key Laboratory of Materials for Energy Conversion, Shanghai Institute of Ceramics, Chinese Academy \\ of Sciences, Shanghai 200050, China; zywen@mail.sic.ac.cn \\ 5 Department of Mechanical Engineering, National University of Singapore, Singapore 117575, Singapore; \\ luli@nus.edu.sg \\ 6 National University of Singapore Suzhou Research Institute, Suzhou 215024, China \\ 7 School of Mechanical Engineering, Hebei University of Technology, Tianjin 300401, China \\ 8 State Key Laboratory of Coal Mine Disaster Dynamics and Control, Chongqing University, \\ Chongqing 400044, China \\ * Correspondence: sfsong@cqu.edu.cn (S.S.); yaojianyao@cqu.edu.cn (J.Y.); ninghu@cqu.edu.cn (N.H.) \\ + These authors contributed equally to this work.
}

Received: 18 March 2019; Accepted: 8 May 2019; Published: 10 May 2019

\begin{abstract}
Garnet $\mathrm{Li}_{7} \mathrm{La}_{3} \mathrm{Zr}_{2} \mathrm{O}_{12}$ is one of the most promising solid electrolytes used for solid-state lithium batteries. However, low ionic conductivity impedes its application. Herein, we report Ta-doping garnets with compositions of $\mathrm{Li}_{7-\mathrm{x}} \mathrm{La}_{3} \mathrm{Zr}_{2-\mathrm{x}} \mathrm{Ta}_{\mathrm{x}} \mathrm{O}_{12}(0.1 \leq \mathrm{x} \leq 0.75)$ obtained by solid-state reaction and free sintering, which was facilitated by graphene oxide (GO). Furthermore, to optimize $\mathrm{Li}_{6.6} \mathrm{La}_{3} \mathrm{Zr}_{1.6} \mathrm{Ta}_{0.4} \mathrm{O}_{12}, \mathrm{Mg}^{2+}$ was select as a second dopant. The dual substitution of $\mathrm{Ta}^{5+}$ for $\mathrm{Zr}^{4+}$ and $\mathrm{Mg}^{2+}$ for $\mathrm{Li}^{+}$with a composition of $\mathrm{Li}_{6.5} \mathrm{Mg}_{0.05} \mathrm{La}_{3} \mathrm{Zr}_{1.6} \mathrm{Ta}_{0.4} \mathrm{O}_{12}$ showed an enhanced total ionic conductivity of $6.1 \times 10^{-4} \mathrm{~S} \mathrm{~cm}^{-1}$ at room temperature. Additionally, spark plasma sintering (SPS) was applied to further densify the garnets and enhance their ionic conductivities. Both SPS specimens present higher conductivities than those produced by the conventional free sintering. At room temperature, the highest ionic conductivity of $\mathrm{Li}_{6.5} \mathrm{Mg}_{0.05} \mathrm{La}_{3} \mathrm{Zr}_{1.6} \mathrm{Ta}_{0.4} \mathrm{O}_{12}$ sintered at $1000{ }^{\circ} \mathrm{C}$ is $8.8 \times 10^{-4} \mathrm{~S} \mathrm{~cm}^{-1}$, and that of $\mathrm{Li}_{6.6} \mathrm{La}_{3} \mathrm{Zr}_{1.6} \mathrm{Ta}_{0.4} \mathrm{O}_{12}$ sintered at $1050{ }^{\circ} \mathrm{C}$ is $1.18 \times 10^{-3} \mathrm{~S} \mathrm{~cm}^{-1}$.
\end{abstract}

Keywords: garnet; dual substitution; spark plasma sintering; conductivity

\section{Introduction}

Nowadays, commercial lithium ion batteries generally employ organic liquid electrolytes, which have caused a series of problems and hindered development of the batteries. The formation of lithium dendrites during cycling lurks between the solid-liquid interface because of the uneven distribution of current and lithium ions, causing safety issues. Moreover, the liquid electrolytes are flammable, exacerbating these safe issues. Therefore, the replacement of liquid electrolytes with solid ones for lithium batteries is of great significance [1,2]. All-solid-state lithium batteries have been widely studied for electric vehicles, rail transit, energy storage and aerospace fields, because of their promising energy density, long cycling life and excellent safety. As one of the most promising solid electrolytes, 
the lithium-rich garnet-type compound with a nominal composition of $\mathrm{Li}_{7} \mathrm{La}_{3} \mathrm{Zr}_{2} \mathrm{O}_{12}$ (LLZO) has many advantages, especially in Li-ion conductivity [3,4]. It has been shown that LLZO exists in two phases, namely a tetragonal phase with an inferior Li-ion conductivity of about $10^{-6} \mathrm{~S} \mathrm{~cm}^{-1}$ at room temperature, and a cubic phase with a superior Li-ion conductivity of about $10^{-4} \mathrm{~S} \mathrm{~cm}^{-1}$ at room temperature. In order to achieve higher conductivities, the content of $\mathrm{Li}$ is usually decreased below $7 \mathrm{Li}$ per formula unit, while the concentration of Li vacancies is increased in LLZO through substitution. It was reported that the replacement of $\mathrm{Zr}^{4+}$ with $\mathrm{Ta}^{5+}$ in LLZO is an effective route to increase the concentration of $\mathrm{Li}$ vacancies and to stabilize the cubic garnet [5]. The other effective solutions to reduce the $\mathrm{Li}$ content are through adding dopants like $\mathrm{Al}^{3+}, \mathrm{Ga}^{3+}$, etc. [6,7]. The principle is occupying the Li sites directly as the same as the substitution at the $\mathrm{Zr}$ sites. Among the dopants, $\mathrm{Mg}^{2+}$ has been reported as a sintering aid which can lower the sintering temperature and improve the relative density. $\mathrm{Mg}^{2+}$ serves as a sintering aid with a mechanism of grain-boundary diffusion and simultaneously suppresses the recrystallization [8]. The most common method for preparing garnet-type solid electrolytes is through the solid state method (SSR) and free sintering, which is widely applied in industry due to its low cost. However, under the condition of a high sintering temperature $\left(>1200{ }^{\circ} \mathrm{C}\right)$ and a long sintering time $(>16 \mathrm{~h})$, it is hard to obtain dense ceramic pellets (relative density $>90 \%$ ) by free sintering. As a result, various advanced sintering technologies have been developed to enhance the relative density, such as hot pressing, flowing oxygen sintering, field-assisted sintering and spark plasma sintering (SPS). It has been reported that the sintering theory of SPS, also famous as field assisted sintering technique (FAST) and pulsed electric current sintering (PECS), is different from the conventional sintering technique. In the sintering process, the DC current flowing through the graphite die generates huge local joule heat. Combining with the uniaxial high pressure, the contact area between particles starts to fuse, resulting in rapid densification $[9,10]$. This principle can effectively improve the relative density and lower the sintering temperature. Besides, it greatly shortens the sintering time and simplifies the process because the sinter does not need the mother powders to compensate the loss of lithium in the vacuum environment [11].

In this work, we investigated a Ta-doped garnet composed of $\mathrm{Li}_{7-\mathrm{x}} \mathrm{La}_{3} \mathrm{Zr}_{2-\mathrm{x}} \mathrm{Ta}_{\mathrm{x}} \mathrm{O}_{12}(\mathrm{x}=0.75,0.6$, $0.5,0.4,0.3,0.2,0.1$ ) (LLZTO) through the traditional method. The preparation process was facilitated by graphene oxide (GO) and was divided into two procedures. Firstly, the raw material was calcined to a cubic precursor at $900{ }^{\circ} \mathrm{C}$ with $1 \mathrm{wt} . \%$ GO with respect to the total mass of the starting materials. The cubic precursor was then sintered at a relatively high temperature. By using GO as a sacrificial template, a nanoscale garnet powder with superior sinterability was produced $[12,13]$. Furthermore, the LLZTO composition was optimized, and Mg was served as the second dopant to further increase the conductivity. In order to compare with the conventional free sintering method and to further improve the ionic conductivity, the optimized Ta-doping and $\mathrm{Ta} / \mathrm{Mg}$ dual substituted samples were sintered via spark plasma sintering.

\section{Experimental}

\subsection{Synthesis and Free Sintering}

LLZTO powders were synthesized by a traditional solid-state method. The primary materials include $\mathrm{LiNO}_{3}(\geq 99.9 \%$, Shanghai Aladdin Biochemical Technology Co. Ltd, Shanghai, China), $\mathrm{MgO}$ (98.0\%, Shanghai Aladdin Biochemical Technology Co. Ltd, Shanghai, China), $\mathrm{La}_{2} \mathrm{O}_{3}(99.9 \%$, Shanghai Aladdin Biochemical Technology Co. Ltd, Shanghai, China), $\mathrm{ZrO}_{2}(99.99 \%$, Shanghai Aladdin Biochemical Technology Co. Ltd, Shanghai, China), and $\mathrm{Ta}_{2} \mathrm{O}_{5}$ (99.5\%, Shanghai Aladdin Biochemical Technology Co. Ltd, Shanghai, China). During the sintering process, a portion of the lithium salt is decomposed into $\mathrm{Li}_{2} \mathrm{O}$ and lost at high temperature [14]. To compensate for the lithium loss, an excess of $\mathrm{LiNO}_{3}$ is added. Actually, we tried different amounts of $\mathrm{LiNO}_{3}$ excess and found that the $40 \mathrm{wt} . \%$ excess was better. It was reported that the excess $\mathrm{Li}_{2} \mathrm{O}$ can densify the lithium garnet by forming glass-like compound at the grain-boundaries, and thus improve the ionic conductivity [15]. $\mathrm{La}_{2} \mathrm{O}_{3}$ was 
dried at $900{ }^{\circ} \mathrm{C}$ for $12 \mathrm{~h}$ to remove the moisture. A total amount of $1 \mathrm{wt} . \% \mathrm{GO}$ with respect to the total mass of the starting materials was added to inhibit the aggregation and to obtain the nano-grains of garnet powders. The preparation of GO adopted an improved Hummers method [16-19]. Firstly, a 10:1 mixture of concentrated $\mathrm{H}_{2} \mathrm{SO}_{4} / \mathrm{H}_{3} \mathrm{PO}_{4}(250: 25 \mathrm{~mL})$ was added to $2 \mathrm{~g}$ graphite flakes (XFNAN, 99.5 wt. $\%, 500 \mu \mathrm{m}$ ) and a slight exotherm was observed. Then, the mixed solution was placed in an ice bath, and $12 \mathrm{~g} \mathrm{KMnO}_{4}$ was slowly added. The solution was well-stirred after being transferred to a magnetic mixer with a constant temperature of $50{ }^{\circ} \mathrm{C}$. After cooling to room temperature, the mixture of $9.56 \mathrm{~mL} 30 \% \mathrm{H}_{2} \mathrm{O}_{2}$ and $134 \mathrm{~mL}$ deionized water was added to the above solution to end the oxidation reaction. To wipe off impurities such as $\mathrm{K}, \mathrm{P}$, and $\mathrm{Mn}$, it is necessary to control the purification process. The raw GO solution was filtered to remove solid impurities and dialyzed through a semi-permeable membrane to remove soluble impurities. Subsequently, the solution was separated into centrifuge tubes and washed by deionized water and dilute hydrochloric acid alternately until the solution approaching to a neutral $\mathrm{pH}$. Finally, the GO solution with a concentration of $3.1 \mathrm{mg} / \mathrm{mL}$ was obtained.

The stoichiometric materials with the GO solution were mixed and ball-milled for $4 \mathrm{~h}$ in 3-Methyl-1-butanol (98.5\%, Aladdin) with a planetary ball-mill machinery, in which zirconia balls and a jar were used. The milling powder was dried in an oven for $3 \mathrm{~h}$ at $90{ }^{\circ} \mathrm{C}$ and pressed into cylindrical pellets. The pellets were placed on a $\mathrm{MgO}$ ceramic wafer in an $\mathrm{Al}_{2} \mathrm{O}_{3}$ crucible so as to isolate from other elements contaminations. After calcined at $900{ }^{\circ} \mathrm{C}$ for $3 \mathrm{~h}$ in air, the pellets were ground to LLZTO powders, and the second ball-milling process was repeated. Then, the LLZTO powders were dried and pressed into cylindrical pellets. Similarly, the samples were covered with corresponding mother powers to reduce lithium loss and sintered at $1100^{\circ} \mathrm{C}$ for $12 \mathrm{~h}$. The obtained ceramic pellets were polished using metallographic abrasive papers with grit numbers of 180, 600 and 1200, respectively. The chemical reactions occurring during the synthesis of LLZTO are as follows:

$$
\begin{array}{r}
4(7-x) \mathrm{LiNO}_{3}+6 \mathrm{La}_{2} \mathrm{O}_{3}+4(2-\mathrm{x}) \mathrm{ZrO}_{2}+2 \mathrm{xTa}_{2} \mathrm{O}_{5}=4 \mathrm{Li}_{7-\mathrm{x}} \mathrm{La}_{3} \mathrm{Zr}_{2-\mathrm{x}} \mathrm{Ta}_{\mathrm{x}} \mathrm{O}_{12}+4(7-\mathrm{x}) \mathrm{NO}_{2} \uparrow+(7-\mathrm{x}) \mathrm{O}_{2} \uparrow \\
260 \mathrm{LiNO}_{3}+2 \mathrm{MgO}+60 \mathrm{La}_{2} \mathrm{O}_{3}+64 \mathrm{ZrO}_{2}+8 \mathrm{Ta}_{2} \mathrm{O}_{5}=40 \mathrm{Li}_{6.5} \mathrm{Mg}_{0.05} \mathrm{La}_{3} \mathrm{Zr}_{1.6} \mathrm{Ta}_{0.4} \mathrm{O}_{12}+260 \mathrm{NO}_{2} \uparrow+65 \mathrm{O}_{2} \uparrow
\end{array}
$$

\subsection{SPS Sintering}

The optimized Ta doping and $\mathrm{Mg} / \mathrm{Ta}$ dual substituted garnets were further sintered by SPS at different temperatures $\left(950^{\circ} \mathrm{C}, 1000^{\circ} \mathrm{C}\right.$ and $\left.1050^{\circ} \mathrm{C}\right)$ for $10 \mathrm{~min}$. The SPS procedure was conducted on a SPS machine (SPS-211Lx, Fuji Radio Engineering Machinery Co., Ltd, Nagoya-shi, Japan) using a graphite mold (30 $\mathrm{mm}$ in height $\times 10.5 \mathrm{~mm}$ in diameter) with two corresponding punches (10 $\mathrm{mm}$ in diameter). Prior to the SPS process, the above-mentioned ceramic chips after testing were re-ground and sieved to obtain uniform fine particles so that the powders could have a better sintering during the SPS procedure. In order to demold easily, the inserted sheets were used to separate the powders and the graphite mold. The SPS was conducted in the vacuum chamber and the heating rate was set to $50{ }^{\circ} \mathrm{C} \mathrm{min}^{-1}$. When the temperature was raised to the target sintering temperature, a static uniaxial pressure of $50 \mathrm{MPa}$ was applied to the samples. After holding for $10 \mathrm{~min}$, the specimens in the chamber were cooled naturally to $600{ }^{\circ} \mathrm{C}$ with pressure decreasing to $5 \mathrm{MPa}$, which contributes the densification of the samples during shrinking. Then, the pressure was removed to avoid the formation of cracks as the temperature naturally cooled down to room temperature. All the procedures were implemented through the setup program controlled under the automatic operation mode. The sintered samples obtained by SPS were polished by the same way as that for previous sintered pellets.

\subsection{Characterization}

The relative density was calculated using the following equation:

$$
\mathrm{d}=\frac{m}{\rho \pi r^{2} l} \times 100 \%
$$




$$
\rho=\frac{M Z}{N_{A} V}
$$

where, $m$ represents the mass, $r$ represents the radius, and $l$ represents the height of the cylinders. The relative density is the ratio of the measured density at room temperature to the theoretical density

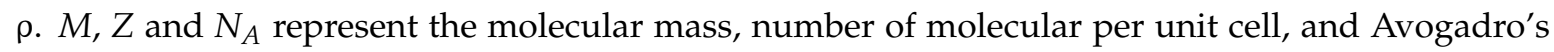
constant, respectively. $V$ represents the cell volume which is decided by the lattice parameter. The final sample is a cylinder-shaped product. The phases of the powders calcined at $900{ }^{\circ} \mathrm{C}$ and $1100{ }^{\circ} \mathrm{C}$ were examined by X-ray diffraction (XRD, D2 PHASER, Bruker, Beijing, China) in the $2 \theta$ range of $10^{\circ}$ and $80^{\circ}$. The $X$-ray data were collected with a step of $0.01^{\circ}$ and a counting time of 0.3 s per step. The cross-sectional morphologies of the pellets were revealed by scanning electron microscopy (SEM, Phenom ProX, Eindhoven, The Netherlands) with an acceleration voltage of $15 \mathrm{kV}$. Electrochemical impedance spectroscopy (EIS) measurements were conducted on the polished pellets. Both surfaces of the pellet were coated with a silver paste as block electrodes. Since the garnet-type electrolyte is prone to react with moisture and carbon dioxide in the air, all ceramic pellets were encapsulated in Swagelok cells in a glove box filled with inert gas. The samples were measured in the temperature range of room temperature and $130^{\circ} \mathrm{C}$. An amplitude of $10 \mathrm{mV}$ and a frequency of $1 \mathrm{MHz}-0.1 \mathrm{~Hz}$ were set on an Autolab PGSTAT302N System. The ionic conductivities were then calculated based on the following equation:

$$
\sigma=\frac{l}{\pi r^{2} R}
$$

where, $l$ represents the height of the cylinders, $r$ represents the radius and $R$ represents the resistance obtained from the impedance chart. Furthermore, the activation energy $E_{a}$, representing the migration barrier of ions, was calculated by the Arrhenius equation:

$$
\sigma \mathrm{T}=\operatorname{Aexp}\left(-E_{a} / \mathrm{kT}\right)
$$

where, $\mathrm{A}, \mathrm{k}$, and $\mathrm{T}$ represent the pre-exponential parameter, Boltzmann constant, and thermodynamic temperature, respectively.

\section{Results and Discussion}

LLZTO powder was synthesized by solid-state reaction with GO as the sacrificial template. As seen in Figure 1a,b, the grain size of the LLZTO powder is about 10-20 nm in the presence of GO, whereas, the grains are 20-30 nm in size and irregular morphology in the absence of GO. It is indicated that the regular and fine grains facilitated sinter, though the aggregation was not completely prevented by GO. The XRD patterns of the Ta-doping garnets with compositions of $\mathrm{Li}_{7-\mathrm{x}} \mathrm{La}_{3} \mathrm{Zr}_{2-\mathrm{x}} \mathrm{Ta}_{\mathrm{x}} \mathrm{O}_{12}(\mathrm{x}=0.75$, $0.6,0.5,0.4,0.3,0.2,0.1)$ calcined at $900{ }^{\circ} \mathrm{C}$ and sintered at $1100{ }^{\circ} \mathrm{C}$ are shown in Figure $1 \mathrm{c}, \mathrm{d}$. As seen in Figure $1 \mathrm{c}$, all the components formed the cubic phase after calcined at $900{ }^{\circ} \mathrm{C}$ except in the range of $x \leq 0.2$, where the mixed cubic and tetragonal phases were found.

It should be noted that the garnets with compositions of $\mathrm{Li}_{6.9} \mathrm{La}_{3} \mathrm{Zr}_{1.9} \mathrm{Ta}_{0.1} \mathrm{O}_{12}$ and $\mathrm{Li}_{6.8} \mathrm{La}_{3} \mathrm{Zr}_{1.8} \mathrm{Ta}_{0.2} \mathrm{O}_{12}$ were not well-pelleted after sintering at $1100^{\circ} \mathrm{C}$. Therefore, the XRD patterns of $\mathrm{Li}_{6.9} \mathrm{La}_{3} \mathrm{Zr}_{1.9} \mathrm{Ta}_{0.1} \mathrm{O}_{12}$ and $\mathrm{Li}_{6.8} \mathrm{La}_{3} \mathrm{Zr}_{1.8} \mathrm{Ta}_{0.2} \mathrm{O}_{12}$ are not presented in Figure $1 \mathrm{~d}$. As seen in Figure $1 \mathrm{~d}$, the garnets with compositions of $\mathrm{Li}_{6.7} \mathrm{La}_{3} \mathrm{Zr}_{1.7} \mathrm{Ta}_{0.3} \mathrm{O}_{12}$ and $\mathrm{Li}_{6.6} \mathrm{La}_{3} \mathrm{Zr}_{1.6} \mathrm{Ta}_{0.4} \mathrm{O}_{12}$ showed the single cubic garnet phase, whereas the garnets with the Ta content of above 0.4 contained some impurities. The single cubic phase indicates fast ion conduction while the impurities hinder ion conduction. The following EIS results also demonstrated the influence of Ta substitution on ionic conductivity. 
(a)

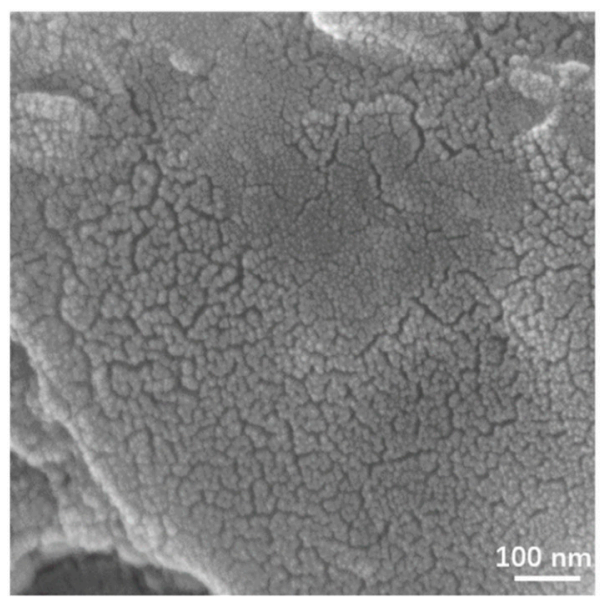

(c)

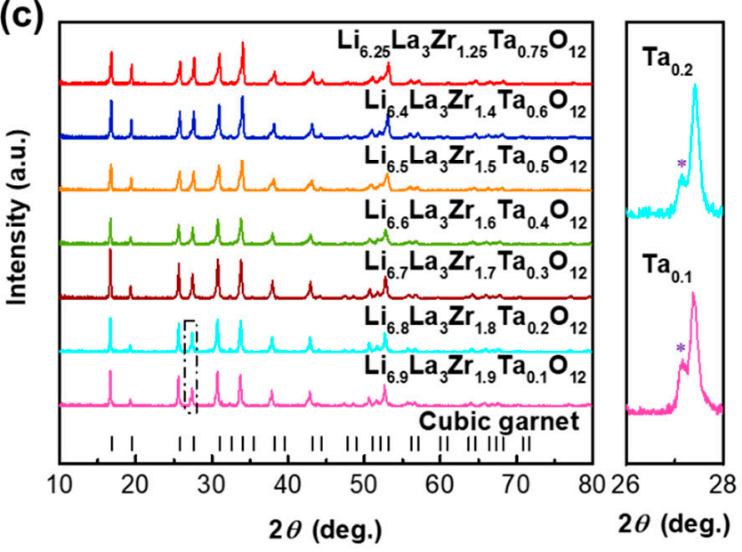

(b)
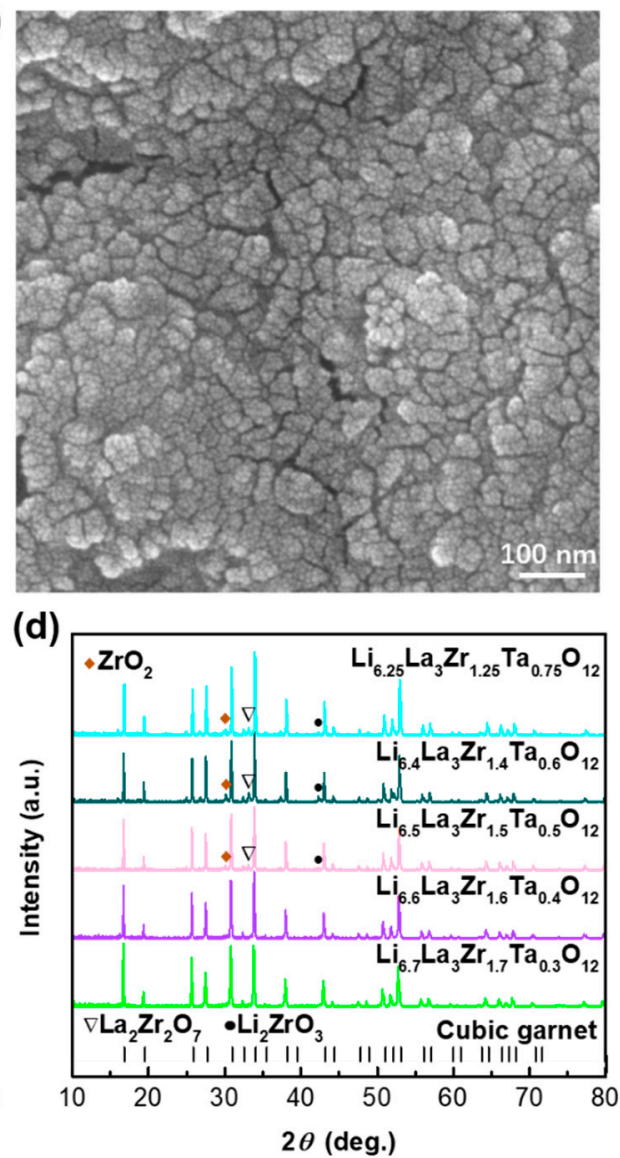

Figure 1. SEM of LLZTO calcined at $900{ }^{\circ} \mathrm{C}$ with GO (a) and without GO (b). The XRD results of the Ta-doping and Ta/Mg-dual substituted garnet calcined at $900{ }^{\circ} \mathrm{C}(\mathbf{c})$ and sintered at $1100{ }^{\circ} \mathrm{C}(\mathrm{d})$. The black vertical lines at the bottom represent the reference cubic garnet (PDF\#45-0109).

The relative densities and ionic conductivities of $\mathrm{Li}_{7-\mathrm{x}} \mathrm{La}_{3} \mathrm{Zr}_{2-\mathrm{x}} \mathrm{Ta}_{\mathrm{x}} \mathrm{O}_{12}(\mathrm{x}=0.75,0.6,0.5,0.4,0.3,0.2$, 0.1 ) sintering by traditional methods are shown in Figure 2. The growing and following declining trend is for relative density to vary with addition of Ta. It is indicated that the enhancement of sinterability might have a significant impact on conductivities. Not unexpectedly, the ionic conductivity showed a noticeable variation. Obviously, it is increased firstly and then decreased with the substitution of Ta for $\mathrm{Zr}$. $\mathrm{Li}_{6.6} \mathrm{La}_{3} \mathrm{Zr}_{1.6} \mathrm{Ta}_{0.4} \mathrm{O}_{12}$ possessed the highest conductivity of about $5.6 \times 10^{-4} \mathrm{~S} \mathrm{~cm}^{-1}$. The increase in relative density is highly beneficial to ion conduction. However, it seems that the variation of ionic conductivity is not always consistent with that of relative density, which proves that relative density is not the unique factor affecting ion conductivity. Besides, the ion conduction was also determined by the crystal structure and the Li content. An excess substitution of $\mathrm{Ta}$ for $\mathrm{Zr}$ led to impurities and a low Li content, which in turn decreased the ionic conductivity. 


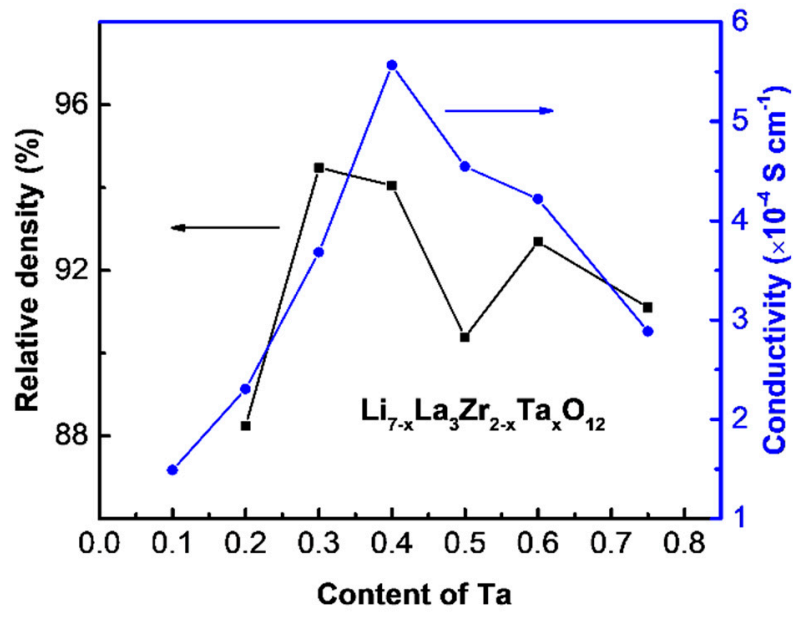

Figure 2. Relative density and ionic conductivity of LLZTO sintering pellets of various components.

The refined lattice parameters of LLZTO have been reported by some groups [20-24]. It can be seen from Table 1 that the lattice parameter of LLZTO increases with the increasing content of Ta. Based on the lattice parameters, the theoretical densities and corresponding relative densities are calculated by Equations (3) and (4).

Table 1. Corresponding lattice parameters reported in the literature and the calculated theoretical densities and relative densities of LLZTO.

\begin{tabular}{lcccc}
\hline \multicolumn{1}{c}{ Compound } & Lattice Parameter (̊) & Ref. & Theoretical Density $\left(\mathbf{g ~ c m}^{\mathbf{3}}\right)$ & Relative Density (\%) \\
\hline $\mathrm{Li}_{6.25} \mathrm{La}_{3} \mathrm{Zr}_{1.25} \mathrm{Ta}_{0.75} \mathrm{O}_{12}$ & $12.91553(6)$ & {$[20]$} & 5.561 & 91.10 \\
$\mathrm{Li}_{6.4} \mathrm{La}_{3} \mathrm{Zr}_{1.4} \mathrm{Ta}_{0.6} \mathrm{O}_{12}$ & 12.923 & {$[21]$} & 5.551 & 92.69 \\
$\mathrm{Li}_{6.5} \mathrm{La}_{3} \mathrm{Zr}_{1.5} \mathrm{Ta}_{0.5} \mathrm{O}_{12}$ & 12.9340 & {$[23]$} & 5.410 & 90.24 \\
$\mathrm{Li}_{6.6} \mathrm{La}_{3} \mathrm{Zr}_{1.6} \mathrm{Ta}_{0.4} \mathrm{O}_{12}$ & 12.939 & {$[24]$} & 5.352 & 94.05 \\
$\mathrm{Li}_{6.7} \mathrm{La}_{3} \mathrm{Zr}_{1.7} \mathrm{Ta}_{0.3} \mathrm{O}_{12}$ & 12.9721 & {$[21]$} & 5.261 & 94.48 \\
$\mathrm{Li}_{6.8} \mathrm{La}_{3} \mathrm{Zr}_{1.8} \mathrm{Ta}_{0.2} \mathrm{O}_{12}$ & 12.9780 & {$[22]$} & 5.203 & 88.24 \\
\hline
\end{tabular}

We subsequently designed a dual substitution of $\mathrm{Mg}$ for $\mathrm{Li}$ and $\mathrm{Ta}$ for $\mathrm{Zr}$ with a composition of $\mathrm{Li}_{6.5} \mathrm{Mg}_{0.05} \mathrm{La}_{3} \mathrm{Zr}_{1.6} \mathrm{Ta}_{0.4} \mathrm{O}_{12}$ based on the optimal composition of $\mathrm{Li}_{6.6} \mathrm{La}_{3} \mathrm{Zr}_{1.6} \mathrm{Ta}_{0.4} \mathrm{O}_{12}$, because $\mathrm{Mg}$ is usually used as the sintering aid. As seen in Figure 3a, the XRD patterns show that $\mathrm{Li}_{6.5} \mathrm{Mg}_{0.05} \mathrm{La}_{3} \mathrm{Zr}_{1.6} \mathrm{Ta}_{0.4} \mathrm{O}_{12}$ exhibits a single cubic phase after calcined at $900{ }^{\circ} \mathrm{C}$, which would be a beneficial effect on the final sinter. $\mathrm{Li}_{6.5} \mathrm{Mg}_{0.05} \mathrm{La}_{3} \mathrm{Zr}_{1.6} \mathrm{Ta}_{0.4} \mathrm{O}_{12}$ demonstrated a single cubic phase after sintered at $1100{ }^{\circ} \mathrm{C}$. The cubic $\mathrm{Li}_{6.5} \mathrm{Mg}_{0.05} \mathrm{La}_{3} \mathrm{Zr}_{1.6} \mathrm{Ta}_{0.4} \mathrm{O}_{12}$ exhibited a relatively high conductivity of $6.1 \times 10^{-4} \mathrm{~S} \mathrm{~cm}^{-1}$ compared with that of $\mathrm{Li}_{6.6} \mathrm{La}_{3} \mathrm{Zr}_{1.6} \mathrm{Ta}_{0.4} \mathrm{O}_{12}$ (Figure 3b). The improved ionic conductivity is probably because the dual substitution promotes the densification and adjusts the Li content.

Figure $4 \mathrm{a}$ shows the relative densities and ionic conductivities of $\mathrm{Li}_{6.6} \mathrm{La}_{3} \mathrm{Zr}_{1.6} \mathrm{Ta}_{0.4} \mathrm{O}_{12}$ and $\mathrm{Li}_{6.5} \mathrm{Mg}_{0.05} \mathrm{La}_{3} \mathrm{Zr}_{1.6} \mathrm{Ta}_{0.4} \mathrm{O}_{12}$ sintered at different temperatures $\left(950{ }^{\circ} \mathrm{C}, 1000{ }^{\circ} \mathrm{C}\right.$, and $\left.1050{ }^{\circ} \mathrm{C}\right)$ by $\mathrm{SPS}$. Since the $\mathrm{Mg}$ content is very low, the lattice parameter of $\mathrm{Li}_{6.5} \mathrm{Mg}_{0.05} \mathrm{La}_{3} \mathrm{Zr}_{1.6} \mathrm{Ta}_{0.4} \mathrm{O}_{12}$ should be similar with that of $\mathrm{Li}_{6.6} \mathrm{La}_{3} \mathrm{Zr}_{1.6} \mathrm{Ta}_{0.4} \mathrm{O}_{12}$ (12.939 $\AA$ [24]). For the relative density, both components showed a general increasing trend with the increase of SPS temperature, indicating that the increasing SPS temperature is in favour of densification. The room-temperature conductivity of the Ta-doping garnet $\mathrm{Li}_{6.6} \mathrm{La}_{3} \mathrm{Zr}_{1.6} \mathrm{Ta}_{0.4} \mathrm{O}_{12}$ was increased with the SPS temperature. $\mathrm{Li}_{6.6} \mathrm{La}_{3} \mathrm{Zr}_{1.6} \mathrm{Ta}_{0.4} \mathrm{O}_{12}$ possessed the highest total (bulk + grain boundary) ionic conductivity of $1.18 \times 10^{-3} \mathrm{~S} \mathrm{~cm}^{-1}$ after treating at a SPS temperature of $1050{ }^{\circ} \mathrm{C}$, while the $\mathrm{Mg} / \mathrm{Ta}$ dual substituted $\mathrm{Li}_{6.5} \mathrm{Mg}_{0.05} \mathrm{La}_{3} \mathrm{Zr}_{1.6} \mathrm{Ta}_{0.4} \mathrm{O}_{12}$ exhibited a different variation. $\mathrm{Li}_{6.5} \mathrm{Mg}_{0.05} \mathrm{La}_{3} \mathrm{Zr}_{1.6} \mathrm{Ta}_{0.4} \mathrm{O}_{12}$ showed the highest total ionic conductivity of $8.8 \times 10^{-4} \mathrm{~S} \mathrm{~cm}^{-1}$ after treating at a SPS temperature of $1000{ }^{\circ} \mathrm{C}$. It indicated that the relatively high lithium content resulted in a relatively high ionic conductivity under a similar densification 
condition. Clearly, the SPS procedure enhanced the ionic conductivity compared with the traditional solid-state reaction. Figure $4 \mathrm{~b}$ shows the dependence of the ionic conductivities on the temperatures for both $\mathrm{Li}_{6.6} \mathrm{La}_{3} \mathrm{Zr}_{1.6} \mathrm{Ta}_{0.4} \mathrm{O}_{12}$ and $\mathrm{Li}_{6.5} \mathrm{Mg}_{0.05} \mathrm{La}_{3} \mathrm{Zr}_{1.6} \mathrm{Ta}_{0.4} \mathrm{O}_{12}$ in the range between room temperature and $130{ }^{\circ} \mathrm{C}$. It can be seen that both samples have a great thermal stability and the activation energies of $\mathrm{Li}_{6.6} \mathrm{La}_{3} \mathrm{Zr}_{1.6} \mathrm{Ta}_{0.4} \mathrm{O}_{12}$ and $\mathrm{Li}_{6.5} \mathrm{Mg}_{0.05} \mathrm{La}_{3} \mathrm{Zr}_{1.6} \mathrm{Ta}_{0.4} \mathrm{O}_{12}$ were calculated to be $0.27 \mathrm{eV}$ and $0.32 \mathrm{eV}$, respectively.
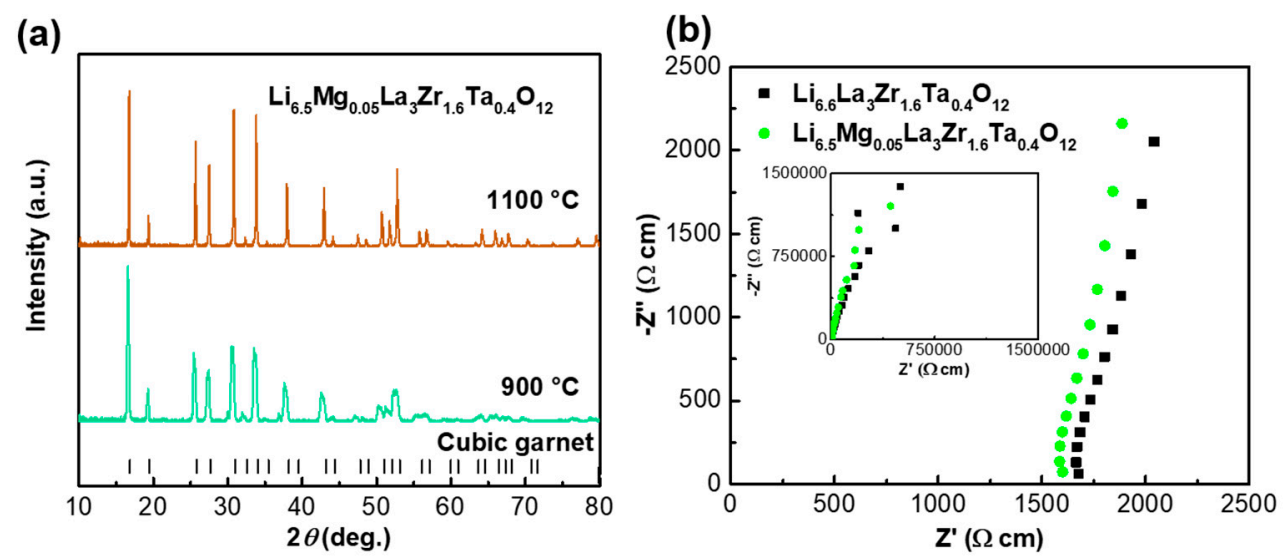

Figure 3. (a) $\mathrm{XRD}$ of $\mathrm{Li}_{6.5} \mathrm{Mg}_{0.05} \mathrm{La}_{3} \mathrm{Zr}_{1.6} \mathrm{Ta}_{0.4} \mathrm{O}_{12}$ treated at $900{ }^{\circ} \mathrm{C}$ and $1100{ }^{\circ} \mathrm{C}$. (b) Nyquist plots of $\mathrm{Li}_{6.6} \mathrm{La}_{3} \mathrm{Zr}_{1.6} \mathrm{Ta}_{0.4} \mathrm{O}_{12}$ and $\mathrm{Li}_{6.5} \mathrm{Mg}_{0.05} \mathrm{La}_{3} \mathrm{Zr}_{1.6} \mathrm{Ta}_{0.4} \mathrm{O}_{12}$ sintered by free sintering; the insets are impedance plots $(10 \mathrm{~Hz}-1 \mathrm{MHz})$ measured in air at room temperature.
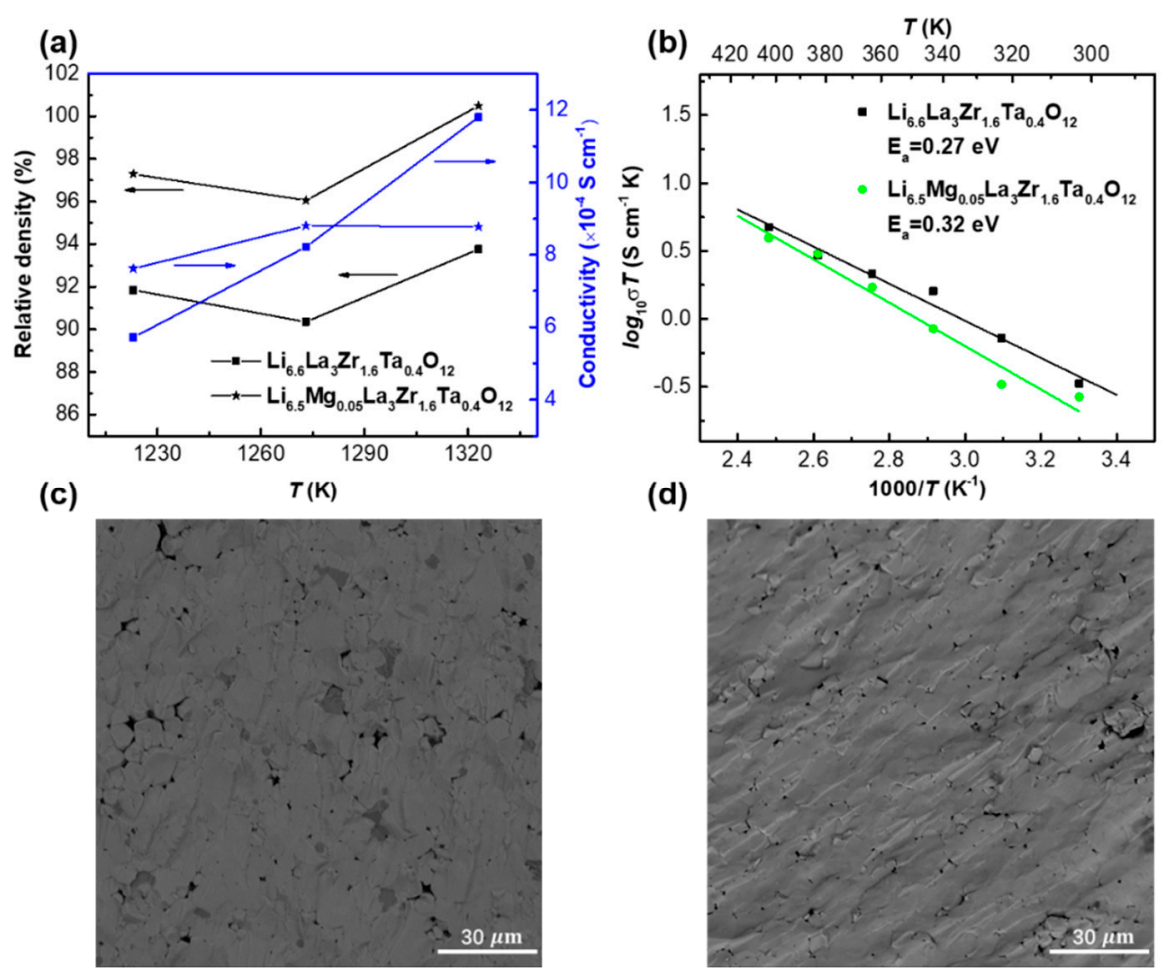

Figure 4. (a) Relative densities and ionic conductivities of $\mathrm{Li}_{6.6} \mathrm{La}_{3} \mathrm{Zr}_{1.6} \mathrm{Ta}_{0.4} \mathrm{O}_{12}$ and $\mathrm{Li}_{6.5} \mathrm{Mg}_{0.05} \mathrm{La}_{3} \mathrm{Zr}_{1.6} \mathrm{Ta}_{0.4} \mathrm{O}_{12}$ sintered by SPS at different temperatures. (b) Arrhenius plots of total ionic conductivities of $\mathrm{Li}_{6.6} \mathrm{La}_{3} \mathrm{Zr}_{1.6} \mathrm{Ta}_{0.4} \mathrm{O}_{12}$ and $\mathrm{Li}_{6.5} \mathrm{Mg}_{0.05} \mathrm{La}_{3} \mathrm{Zr}_{1.6} \mathrm{Ta}_{0.4} \mathrm{O}_{12}$ sintered by SPS. The dash points are experimental values and the solid lines are the fitting ones. The cross-section SEM of $\mathrm{Li}_{6.6} \mathrm{La}_{3} \mathrm{Zr}_{1.6} \mathrm{Ta}_{0.4} \mathrm{O}_{12}$ (c) and of $\mathrm{Li}_{6.5} \mathrm{Mg}_{0.05} \mathrm{La}_{3} \mathrm{Zr}_{1.6} \mathrm{Ta}_{0.4} \mathrm{O}_{12}(\mathbf{d})$ after conducting SPS at $1000{ }^{\circ} \mathrm{C}$. 
The cross-section SEM micrographs of the specimens obtained from the SPS process are shown in Figure 4c,d. It can be seen that SPS specimens possessed a remarkable densification, same with the previous reports $[9,10]$. The fracture only occurred within the grain, not at the grain boundary, indicating the cohesive force between particles was increased, which strengthened the integration of the grain boundary. The increased density of the microstructure improved the ion conduction.

The uniform distribution of garnet elements is illustrated in the EDS mapping. As shown in Figure 5, elements $\mathrm{La}, \mathrm{Zr}, \mathrm{Ta}$, and Mg were uniformly distributed in the grains. There is no obvious trace of $\mathrm{Mg}$ in grain-boundaries, which proved that most of element $\mathrm{Mg}$ is probably integrated to the lattice.

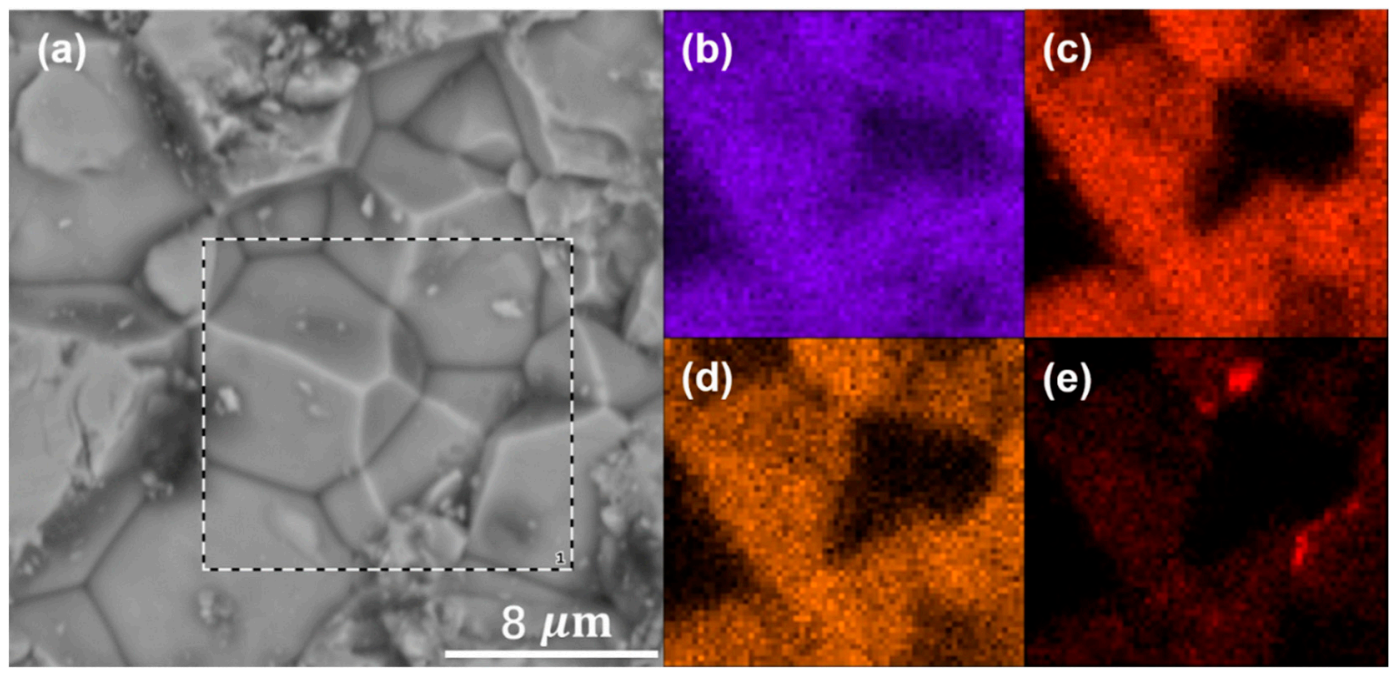

Figure 5. EDS mapping on the surface of $\mathrm{Li}_{6.5} \mathrm{Mg}_{0.05} \mathrm{La}_{3} \mathrm{Zr}_{1.6} \mathrm{Ta}_{0.4} \mathrm{O}_{12}$ sintered by SPS at $1050{ }^{\circ} \mathrm{C}$ : (a) mapping area, (b) La, (c) $\mathrm{Zr}$, (d) Ta, and (e) Mg.

\section{Conclusions}

In summary, the dual substitution of $\mathrm{Ta}$ for $\mathrm{Zr}$ and $\mathrm{Mg}$ for $\mathrm{Li}$ on the structure and performance of garnet $\mathrm{Li}_{7} \mathrm{La}_{3} \mathrm{Zr}_{2} \mathrm{O}_{12}$ is investigated. The newly-developed garnet with a composition of $\mathrm{Li}_{6.5} \mathrm{Mg}_{0.05} \mathrm{La}_{3} \mathrm{Zr}_{1.6} \mathrm{Ta}_{0.4} \mathrm{O}_{12}$ shows a single cubic phase and exhibits a relatively high total ionic conductivity of $6.1 \times 10^{-4} \mathrm{~S} \mathrm{~cm}^{-1}$, which is slightly higher than that of bare $\mathrm{Li}_{6.6} \mathrm{La}_{3} \mathrm{Zr}_{1.6} \mathrm{Ta}_{0.4} \mathrm{O}_{12}$. It may be because the dopant $\mathrm{Mg}$ facilitates the densification. Spark plasma sintering is further applied on $\mathrm{Li}_{6.6} \mathrm{La}_{3} \mathrm{Zr}_{1.6} \mathrm{Ta}_{0.4} \mathrm{O}_{12}$ and $\mathrm{Li}_{6.5} \mathrm{Mg}_{0.05} \mathrm{La}_{3} \mathrm{Zr}_{1.6} \mathrm{Ta}_{0.4} \mathrm{O}_{12}$. The results verify that the SPS process is an effective technology to densify the cubic garnet. Both $\mathrm{Li}_{6.6} \mathrm{La}_{3} \mathrm{Zr}_{1.6} \mathrm{Ta}_{0.4} \mathrm{O}_{12}$ and $\mathrm{Li}_{6.5} \mathrm{Mg}_{0.05} \mathrm{La}_{3} \mathrm{Zr}_{1.6} \mathrm{Ta}_{0.4} \mathrm{O}_{12}$ show dense microstructures at SPS temperature of $1000{ }^{\circ} \mathrm{C}$. $\mathrm{Li}_{6.6} \mathrm{La}_{3} \mathrm{Zr}_{1.6} \mathrm{Ta}_{0.4} \mathrm{O}_{12}$ possesses the highest room-temperature conductivity of $1.18 \times 10^{-3} \mathrm{~S} \mathrm{~cm}^{-1}$ after SPS treatment at $1050{ }^{\circ} \mathrm{C}$, while $\mathrm{Li}_{6.5} \mathrm{Mg}_{0.05} \mathrm{La}_{3} \mathrm{Zr}_{1.6} \mathrm{Ta}_{0.4} \mathrm{O}_{12}$ shows a conductivity of $8.8 \times 10^{-4} \mathrm{~S} \mathrm{~cm}^{-1}$ after SPS procedure at $1000^{\circ} \mathrm{C}$. It is indicated that the relatively high lithium content results in a high ionic conductivity under a similar densification condition.

Author Contributions: S.S. and N.H. conceived the ideas. Z.D. performed the synthesis and characterization of materials. C.X. carried out the SPS experiment part. S.S. and Z.D. analysed the data and wrote the paper. All authors discussed and commented on the paper.

Funding: This work was supported by the National Natural Science Foundation of China (No. 51702030, No. 11632004, and No. U1864208), Shanghai Aerospace Science and Technology Innovation Foundation (No. SAST2017-137), Chongqing University, the Fundamental Research Funds for the Central Universities (No. 2018CDXYHK0016), the Key Program for International Science and Technology Cooperation Projects of the Ministry of Science and Technology of China (No. 2016YFE0125900).

Conflicts of Interest: The authors declare no conflict of interest. 


\section{References}

1. Wang, Q.S.; Jiang, L.H.; Yu, Y.; Sun, J.H. Progress of enhancing the safety of lithium ion battery from the electrolyte aspect. Nano Energy 2019, 55, 93-114. [CrossRef]

2. Liu, X.Y.; Li, X.R.; Li, H.X.; Wu, H.B. Recent Progress of Hybrid Solid-State Electrolytes for Lithium Batteries. Chem.-Eur. J. 2018, 24, 18293-18306. [CrossRef] [PubMed]

3. Tsai, C.L.; Ma, Q.L.; Dellen, C.; Lobe, S.; Vondahlen, F.; Windmuller, A.; Gruner, D.; Zheng, H.; Uhlenbruck, S.; Finsterbusch, M.; et al. A garnet structure-based all-solid-state Li battery without interface modification: Resolving incompatibility issues on positive electrodes. Sustain. Energ. Fuels 2019, 3, 280-291. [CrossRef]

4. Yeandel, S.R.; Chapman, B.J.; Slater, P.R.; Goddard, P. Structure and lithium-ion dynamics in fluoride-doped cubic $\mathrm{Li}_{7} \mathrm{La}_{3} \mathrm{Zr}_{2} \mathrm{O}_{12}$ (LLZO) garnet for Li solid-state battery applications. J. Phys. Chem. C 2018, 122, 27811-27819. [CrossRef]

5. El-Shinawi,H.; Cussen, E.J.; Corr, S.A. Enhancement of the lithium ion conductivity of Ta-doped $\mathrm{Li}_{7} \mathrm{La}_{3} \mathrm{Zr}_{2} \mathrm{O}_{12}$ by incorporation of calcium. Dalton Trans. 2017, 46, 9415-9419. [CrossRef] [PubMed]

6. Allen, J.L.; Wolfenstine, J.; Rangasamy, E.; Sakamoto, J. Effect of substitution (Ta, Al, Ga) on the conductivity of $\mathrm{Li}_{7} \mathrm{La}_{3} \mathrm{Zr}_{2} \mathrm{O}_{12}$. J. Power Sources 2012, 206, 315-319. [CrossRef]

7. Wolfenstine, J.; Ratchford, J.; Rangasamy, E.; Sakamoto, J.; Allen, J.L. Synthesis and high Li-ion conductivity of Ga-stabilized cubic $\mathrm{Li}_{7} \mathrm{La}_{3} \mathrm{Zr}_{2} \mathrm{O}_{12}$. Mater. Chem. Phys. 2012, 134, 571-575. [CrossRef]

8. Yang, X.F.; Kong, D.B.; Chen, Z.P.; Sun, Y.Y.; Liu, Y.Q. Low-temperature fabrication for transparency Mg doping $\mathrm{Li}_{7} \mathrm{La}_{3} \mathrm{Zr}_{2} \mathrm{O}_{12}$ solid state electrolyte. J. Mater. Sci.-Mater. Electron. 2018, 29, 1523-1529. [CrossRef]

9. Zhang, Y.; Fei, C.; Rong, T.; Qiang, S.; Zhang, L. Field assisted sintering of dense Al-substituted cubic phase $\mathrm{Li}_{7} \mathrm{La}_{3} \mathrm{Zr}_{2} \mathrm{O}_{12}$ solid electrolytes. J. Power Sources 2014, 268, 960-964. [CrossRef]

10. Yamada, H.; Ito, T.; Basappa, R.H. Sintering mechanisms of high-performance garnet-type solid electrolyte densified by spark plasma sintering. Electrochim. Acta 2016, 222, 648-656. [CrossRef]

11. Baek, S.W.; Lee, J.M.; Kim, T.Y.; Song, M.S.; Park, Y. Garnet related lithium ion conductor processed by spark plasma sintering for all solid state batteries. J. Power Sources 2014, 249, 197-206. [CrossRef]

12. Benavente, R.; Pruna, A.; Borrell, A.; Salvador, M.D.; Pullini, D.; Penaranda-Foix, F.; Busquets, D. Fast route to obtain $\mathrm{Al}_{2} \mathrm{O}_{3}$-based nanocomposites employing graphene oxide: Synthesis and sintering. Mater. Res. Bull. 2015, 64, 245-251. [CrossRef]

13. Gordon, Z.D.; Yang, T.; Morgado, G.B.G.; Chan, C.K. Preparation of nano- and microstructured garnet $\mathrm{Li}_{7} \mathrm{La}_{3} \mathrm{Zr}_{2} \mathrm{O}_{12}$ solid electrolytes for Li-ion batteries via cellulose templating. ACS Sustain. Chem. Eng. 2016, 4, 6391-6398. [CrossRef]

14. Liu, K.; Ma, J.T.; Wang, C.A. Excess lithium salt functions more than compensating for lithium loss when synthesizing $\mathrm{Li}_{6.5} \mathrm{La}_{3} \mathrm{Ta}_{0.5} \mathrm{Zr}_{1.5} \mathrm{O}_{12}$ in alumina crucible. J. Power Sources 2014, 260, 109-114. [CrossRef]

15. Li, Y.Q.; Cao, Y.; Guo, X.X. Influence of lithium oxide additives on densification and ionic conductivity of garnet-type $\mathrm{Li}_{6.75} \mathrm{La}_{3} \mathrm{Zr}_{1.75} \mathrm{Ta}_{0.25} \mathrm{O}_{12}$ solid electrolytes. Solid State Ionics 2013, 253, 76-80. [CrossRef]

16. Chowdhury, T.; Zhang, L.; Zhang, J.; Aggarwal, S. Removal of arsenic(III) from aqueous solution using metal organic framework-graphene oxide nanocomposite. Nanomaterials 2018, 8, 1062. [CrossRef]

17. Hummers, W.S.; Offeman, R.E. Preparation of graphitic oxide. J. Am. Chem. Soc. 1958, 80, 1339. [CrossRef]

18. Marcano, D.C.; Kosynkin, D.V.; Berlin, J.M.; Sinitskii, A.; Sun, Z.Z.; Slesarev, A.; Alemany, L.B.; Lu, W.; Tour, J.M. Improved synthesis of graphene oxide. ACS Nano 2010, 4, 4806-4814. [CrossRef]

19. Zhang, Y.; Ma, J.; Bai, Y.; Wen, Y.; Zhao, N.; Zhang, X.; Zhang, Y.; Li, Q.; Wei, L. The preparation and properties of nanocomposite from bio-based polyurethane and graphene oxide for gas separation. Nanomaterials 2019, 9, 15. [CrossRef]

20. Logeat, A.; Koohler, T.; Eisele, U.; Stiaszny, B.; Harzer, A.; Tovar, M.; Senyshyn, A.; Ehrenberg, H.; Kozinsky, B. From order to disorder: The structure of lithium-conducting garnets $\mathrm{Li}_{7-\mathrm{x}} \mathrm{La}_{3} \mathrm{Ta}_{\mathrm{x}} \mathrm{Zr}_{2-\mathrm{x}} \mathrm{O}_{12}(\mathrm{x}=0-2)$. Solid State Ionics 2012, 206, 33-38. [CrossRef]

21. Thangadurai, V.; Narayanan, S.; Pinzaru, D. Garnet-type solid-state fast Li ion conductors for Li batteries: Critical review. Chem. Soc. Rev. 2014, 43, 4714-4727. [CrossRef]

22. Wang, Y.X.; Lai, W. High ionic conductivity lithium garnet oxides of $\mathrm{Li}_{7-\mathrm{x}} \mathrm{La}_{3} \mathrm{Zr}_{2-\mathrm{x}} \mathrm{Ta}_{\mathrm{x}} \mathrm{O}_{12}$ compositions. Electrochem. Solid State Lett. 2012, 15, A68-A71. [CrossRef] 
23. Li, Y.T.; Xu, B.Y.; Xu, H.H.; Duan, H.N.; Lu, X.J.; Xin, S.; Zhou, W.D.; Xue, L.G.; Fu, G.T.; Manthiram, A.; et al. Hybrid polymer/garnet electrolyte with a small interfacial resistance for lithium-ion batteries. Angew. Chem.-Int. Ed. 2017, 56, 753-756. [CrossRef]

24. Schleutker, M.; Bahner, J.; Tsai, C.L.; Stolten, D.; Korte, C. On the interfacial charge transfer between solid and liquid $\mathrm{Li}^{+}$electrolytes. Phys. Chem. Chem. Phys. 2017, 19, 26596-26605. [CrossRef]

(C) 2019 by the authors. Licensee MDPI, Basel, Switzerland. This article is an open access article distributed under the terms and conditions of the Creative Commons Attribution (CC BY) license (http://creativecommons.org/licenses/by/4.0/). 